Jurnal Mahasiswa BK An-Nur : Berbeda, Bermakna, Mulia

Volume 7 Nomor 3 Tahun 2021

Tersedia Online: https://ojs.uniska-bjm.ac.id/index.php/AN-NUR

p-ISSN. 2460-9722 | e-ISSN. 2622-8297

\title{
HUBUNGAN ANTARA KELEKATAN ANAK PADA IBU DAN KEPERCAYAAN DIRI DENGAN KEMANDIRIAN SISWA TK IT ULUL ALBAAB WELERI
}

\author{
Siti Lismawati ${ }^{1}$, Laelatul Anisah ${ }^{2}$, Mochamad Widjanarko ${ }^{3}$ \\ ${ }^{1}$ Universitas Selamat Sri \\ ${ }^{2}$ Universitas Selamat Sri \\ ${ }^{3}$ Universitas Muria Kudus
}

E-mail: laelatulanisah89@gmail.com/No. HP 08112512511

\begin{abstract}
ABSTRAK
Anak memiliki kelekatan dengan ibu akan memberikan efek rasa aman walaupun figure lekat (ibu) tidak tampak dalam pandangan anak. Dengan demikian anak yang memiliki kelekatan yang aman dengan ibu akan menunjukkan perilaku positif seperti mandiri dan memiliki kepercayaan diri serta memiliki hubungan baik dengan orang lain. Penelitian ini bertujuan untuk mengetahui hubungan antara kelekatan anak pada Ibu dan kepercayaan diri dengan kemandirian siswa TK IT Ulul Albaab Weleri. Hipotesis yang diajukan pada penelitian ini ada tiga yakni: hipotesis mayor menunjukan adanya hubungan antara kelekatan anak pada Ibu dan kepercayaan diri dengan kemandirian siswa TK IT Ulul Albaab Weleri. Hipotesis minor satu menunjukan adanya hubungan positif antara kelekatan anak pada ibu dengan dengan kemandirian siswa TK IT Ulul Albaab Weleri. Sedangkan hipotesis minor dua menunjukan adanya hubungan positif antara kepercayaan diri dengan kemandirian siswa TK IT Ulul Albaab Weleri. Subjek penelitian ini adalah 60 wali murid TK IT Ulul Albaab Weleri. Metode analisis data menggunakan teknik korelasi product moment. Hasil pengujian hipotesis mayor dengan menggunakan analisis regresi sederhana menunjukkan hasil $\mathrm{Rx} 1,2 \mathrm{y}=0,587$ dengan $\mathrm{F}=14,986$ dan $\mathrm{p}=$ $0,000(\mathrm{p}<0,01)$. Hasil tersebut menunjukkan bahwa terdapat hubungan yang sangat signifikan antara kelekatan anak pada ibu, kepercayaan diri dengan kemandirian pada siswa di TK IT Ulul Albaab Weleri. Variabel kelekatan ada pada kategori tinggi dengan prosentase $13 \%$ sebanyak 8 anak dan kepercayaan diri ada pada kategori tinggi dengan prosentase $15 \%$ sebanyak 15 anak. Variabel kemandirian memiliki kategori tinggi dengan prosentase $10 \%$ sebanyak 6 anak.
\end{abstract}

Kata kunci : Kelekatan anak pada ibu, kepercayaan diri dan kemandirian.

\begin{abstract}
This research aims to find out the relationship between child attachment to motherhood and confidence with the independence of IT kindergarten student Ulul Albaab Weleri. The hypothesis presented in this study is three: the major hypothesis shows a link between the attachment of the child to motherhood and confidence with the independence of IT kindergarten student Ulul Albaab Weleri. The minor hypothesis shows a positive relationship between the attachment of the child to the mother and the independence of IT kindergarten student Ulul Albaab Weleri, while the two minor hypotheses show a positive relationship between confidence and selfreliance of IT kindergarten student Ulul Albaab Weleri. The subjects of this student guardian 60 IT kindergarten students Ulul Albaab Weleri. The study used cluster random sampling. The results of major hypothesis tests using a simple regression analysis showed results of $R x 12 y=0.587$ with $F=14,986$ and $p=0.000(p<0.01)$. The results showed that there was a very significant link between the attachment of the child to the mother, confidence and self-reliance in the students at TK IT Ulul Albaab Weleri. While the results of minor hypothesis testing use the data analysis method with the product-moment correlation technique. Based on an analysis on the minor hypothesis one showed a very significant positive relationship between the child's attachment variable in the mother and self-reliance, indicated by a value of $r x 1 y=0.576$ with $p=0.000(p<0.01)$. The two minor hypothesis tests showed a very significant positive relationship between confidence variables and self-reliance, indicated by a value of rx $2 y=0.496$ to $p=0.000(p<0.01)$.
\end{abstract}

Keywords: conformity, self-confidence, consumptive behaviour

Dipublikasikan Oleh :

UPT Publikasi dan Pengelolaan Jurnal

Universitas Islam Kalimantan Muhammad Arsyad Al-Banjari Banjarmasin 
Siti Lismawati ${ }^{1}$, Laelatul Anisah ${ }^{2}$, Mochamad Widjanarko ${ }^{3}$ Jurnal Mahasiswa BK An-Nur : Berbeda, Bermakna, Mulia

Volume 7 Nomor 3 Tahun 2021

Tersedia Online: https://ojs.uniska-bjm.ac.id/index.php/AN-NUR p-ISSN. 2460-9722 | e-ISSN. 2622-8297

\section{PENDAHULUAN}

Anak adalah rahmat Allah dan amanat Allah, penguji iman, media beramal, bekal diakhirat, sumber kebahagiaan, tempat bergantung di hari tua, penyambung cita-cita, dan seseorang yang harus dididik (Suryana, 2020). Mengingat bahwa masa anak perlu dilindungi, maka untuk menghindari rentannya berbagai perilaku yang mengganggu pertumbuhan anak tersebut UU Nomor 23 Tahun 2002 tentang Perlindungan Anak Pasal 2 dinyatakan bahwa penyelenggaraan perlindungan anak berasaskan Pancasila dan Undang-Undang Dasar 1945 serta prinsip-prinsip dasar Konvensi Hak-hak Anak (KHA) meliputi non diskriminasi, kepentingan yang terbaik bagi anak, hak untuk hidup, kelangsungan hidup dan perkembangan, penghargaan terhadap pendapat anak. Dengan demikian tanggungjawab orang tua atas kesejahteraan anaknya untuk merawat, membimbing, membina, mendidik dan menumbuh kembangkan potensi yang dimiliki anak sehingga anak dapat tumbuh dan berkembang menjadi generasi sehat, cerdas, berakhlakul karimah, berbakti kepada orang tua, bertakwa kepada Tuhan Yang Maha Esa dan berguna bagi nusa dan bangsa.

Menurut Upton (2012), banyak hal yang dilakukan sepanjang hari untuk mendorong anak bertindak mandiri, namun hal ini bukan berarti meninggalkan anak untuk melakukannya sendiri. Hal ini diperkuat Chaplin (dalam Desmita, 2011) dalam kamus besar psikologi berasal dari kata "indepedence" yang diartikan sebagai suatu kondisi dimana seseorang tidak tergantung pada orang lain dalam menentukan keputusan dan adanya sikap percaya diri. Menurut Desmita (2011), salah satu tujuan yang ingin dicapai orang tua dalam mendidik anak-anaknya adalah tumbuh menjadi anak mandiri.

Menurut Sjarkawi (2010), menegakkan kemandirian sangat bergantung pada tiga hal, salah satunya ialah kelekatan orangtua-anak. Menurut Andreassen dan Fletcher (dalam Ionescu, 2014), menyatakan terbentuknya awal hubungan yang hangat dan responsif antara anak dengan orang dewasa yang signifikan akan bertindak sebagai faktor pelindung untuk anak-anak. Menurut Eliasa (2011), proses pembetukan kelekatan didasarkan pada kepercayaan anak terhadap penerimaan lingkungan akan mengembangkan kelekatan yang aman dengan figure lekatnya dan mengembangkan rasa percaya tidak hanya pada ibu dan lingkungan.

Hal ini akan berdampak positif terhadap proses perkembangan anak. Anak dengan pola kelekatan aman akan memiliki kemampuan sosial yang baik pada masa kanak-kanak dan mudah beradaptasi dengan lingkungan sosial (Eliasa, 2011). Eliasa juga menambahkan bahwa anak dengan pola kelekatan aman lebih mampu membina hubungan persahabatan yang intens, interaksi yang harmonis, responsif dan tidak mendominasi. Selain dipengaruhi oleh kelekatan orangtua terhadap anak, terdapat faktor lain yang mempengaruhi kemandirian diantaranya yaitu memiliki rasa percaya diri (Benjamin dalam Nayla 2010).

Lauster (2013), mengatakan bahwa kepercayaan diri merupakan suatu sikap dan perasaan yakin akan kemampuan diri sendiri sehingga orang yang bersangkutan tidak terlalu cemas dalam tindakan-tindakannya, merasa bebas untuk melakukan hal- hal yang sesuai dengan keinginannya dan bertanggungjawab atas perbuatannya, hangat dan sopan dalam dalam berinteraksi dengan orang lain, memiliki dorongan berprestasi serta dapat mengenal kelebihan dan kekurangannya. fenomena yang terjadi di salah satu TK di Weleri dimana kondisi siswa masih mendapatkan kelekatan yang kurang sesuai dengan anak. Selain itu anak belum percaya diri melakukan sesuatu jika ada ibunya dengan demikian peneliti tertarik untuk melakukan penelitian dengan tujuan untuk melihat apakah ada hubungan antara kelekatan anak pada ibu dan kepercayaan diri dengan kemandirian pada siswa.

Manfaat secara teoritis penelitian ini dapat menambah wawasan dan mengembangkan ilmu yang berkaitan dengan kelekatan anak pada ibu dan kepercayaan diri dengan kemandirian anak khususnya pada bidang ilmu psikologi anak usia dini. Sedangkan manfaat praktis diharapkan memberi pengetahuan kepada orang tua terutama ibu tentang konsep kelekatan yang dibangun ibu kepada anak dan kepercayaan diri terhadap kemandirian. Selain itu penelitian dapat menjadi referensi bagi peneliti lain untuk dapat menyusun penelitian yang serupa dengan penelitian kelekatan anak pada ibu dan kepercayaan diri dengan kemandirian.

Hipotesis mayor dalam penelitian ini yaitu ada hubungan antara kelekatan anak pada ibu dan kepercayaan diri dengan Kemandirian siswa TK IT

Dipublikasikan Oleh :

UPT Publikasi dan Pengelolaan Jurnal

Universitas Islam Kalimantan Muhammad Arsyad Al-Banjari Banjarmasin 
Siti Lismawati ${ }^{1}$, Laelatul Anisah ${ }^{2}$, Mochamad Widjanarko ${ }^{3}$ Jurnal Mahasiswa BK An-Nur : Berbeda, Bermakna, Mulia

Volume 7 Nomor 3 Tahun 2021

Tersedia Online: https://ojs.uniska-bjm.ac.id/index.php/AN-NUR

p-ISSN. 2460-9722 | e-ISSN. 2622-8297

Ulul Albaab Weleri. Sedangkan hipotesis minor satu dalam penelitian ini yaitu ada hubungan positif antara kelekatan anak pada ibu dengan kemandirian, artinya semakin tinggi kelekatan anak maka semakin tinggi kemandirian, demikian juga sebaliknya. Hipotesis minor yang kedua yaitu Ada hubungan Positif antara kepercayaan diri dengan kemandirian, artinya semakin tinggi kepercayaan diri yang dimiliki anak maka semakin tinggi kemandirian, demikian juga sebaliknya.

\section{METODE}

\section{Identifikasi Variabel Penelitian}

$\begin{array}{ll}\text { Variabel tergantung } & \begin{array}{l}\text { Kelekatan anak } \\ \text { Kepercayaan }\end{array} \\ \text { Variabel bebas } & : \text { Kemandirian }\end{array}$

\section{Subjek penelitian}

Subjek penelitian ini yaitu wali murid TK IT Ulul Albaab Weleri berjumlah 60 responden. Teknik pengambilan sampel pada penelitian ini menggunakan sample random sampling.

\section{Alat pengumpul data}

Skala kemandirian yang digunakan disusun oleh Fatimah (dalam Nurhayati, 2010) meliputi: kemandirian emosi, kemandirian ekonomi, kemandirian intelektual dan kemandirian sosial. Skala kelekatan yang digunakan disusun oleh oleh Bowbly (dalam Cenceng, 2015). Pola kelekatan menurut Bowbly (dalam Cenceng, 2015) meliputi: Secure Attachment (pola aman), resistant attachment (pola melawan), avoidant attachment (pola menghindar). Skala kepercayaan diri yang digunakan 4 disusun oleh oleh Lauster (dalam Ghufron dan Risnawita, 2016) meliputi keyakinan kemampuan diri, optimis, objektif, bertanggung jawab, dan rasional dan realistis.

\section{Metode Analisi Data}

Teknik atau metode analisis data yang digunakan untuk menguji hipotesis yaitu product moment.

\section{HASIL DAN PEMBAHASAN}

\section{Uji normalitas}

Uji normalitas dilakukan dengan teknik Kolmogorov - SmirnovZ pada program SPSS 15.00 for Windows menunjukkan bahwa variabel kelekatan anak nilai $\mathrm{K}-\mathrm{SZ}=1,158$ dengan $\mathrm{p}=0,137(\mathrm{p}>0,05)$, dan uji normalitas pada variabel kepercayaan diri diperoleh nilai $\mathrm{K}-\mathrm{SZ}=1,079$ dengan $\mathrm{p}=0,195$ $(\mathrm{p}>0,05)$, sedangkan uji normalitas variabel kemandirian diperoleh nilai $\mathrm{K}-\mathrm{SZ}=0,790$ dengan $\mathrm{p}=$ $0,560(\mathrm{p}>0,05)$. Dari uji normalitas ini menunjukan bahwa ketiga variabel tersebut memiliki sebaran data yang normal. Selengkapnya dapat dilihat pada tabel 1 .

2. Uji linieritas

Uji linieritas hubungan pada penelitian ini terdiri dari dua hasil, dimana hasil pertama bertujuan untuk mengetahui hubungan antara kelekatan dengan kemandirian, sedangkan hasil kedua bertujuan untuk mengetahui hubungan antara kepercayaan diri dengan kemandirian. Uji linieritas hubungan pertama menunjukkan adanya hubungan antara variabel kelekatan dan kemandirian, dimana FLinier $=1,218$ dengan $\mathrm{p}=0,295(\mathrm{p}>0,05)$. Uji linieritas hubungan kedua menunjukkan adanya hubungan antara variabel kepercayaan diri dan kemandirian dimana FHitung = 8,25 dengan $p=0,701(p>0,05)$. Selengkapnya dapat dilihat pada tabel 2 dan 3 .

\section{Uji Multikolinieritas}

Uji multikolonieritas dilakukan untuk menguji model regresi apakah ditemukan adanya hubungan antara variabel bebas 1 dan variabel bebas 2 . Uji multikolinieritas pada penelitian ini menggunakan bantuan program SPSS 15.00 for Windows dengan teknik Regresi berganda dan menggunakan metode VIF (Variance Inflation Factor). Hasil uji multikolinieritas antar variabel bebas (Kelekatan dan Kepercayaan Diri) menunjukkan tidak terjadinya multikolinieritas, karena nilai tolerance kedua variabel bebas bernilai $0,133(>0,1)$ dan nilai $V I F$ kedua variabel bebas bernilai 7,524 (<10). Selengkapnya dapat dilihat pada tabel 4.

Uji hipotesis mayor

Uji hipotesis mayor yang dilakukan dengan teknik korelasi Analisis regresi sederhana pada program SPSS 15.00 for Windows menunjukkan adanya hubungan yang signifikan antara variabel kelekatan anak pada ibu dan kepercayaan diri dengan kemandirian pada siswa TK IT Ulul Albaab Weleri, dimana koefisiensi dari ketiga variabel hasil $\mathrm{Rx} 1,2 \mathrm{y}=$ 0,587 dengan FHitung $=14,986$ dan $p=0,000$ $(\mathrm{p}<0,01)$. Dengan demikian hipotesis mayor yang diajukan dalam penelitian ini diterima. Selengkapnya dapat dilihat pada tabel 5 .

5. Uji hipotesis minor satu

Uji hipotesis minor satu yang dilakukan dengan teknik korelasi Product Moment pada program SPSS 15.00 for Windows menunjukkan adanya hubungan positif yang signifikan antara variabel kelekatan anak pada ibu dengan kemandirian, dimana

Dipublikasikan Oleh :

UPT Publikasi dan Pengelolaan Jurnal

Universitas Islam Kalimantan Muhammad Arsyad Al-Banjari Banjarmasin 
Siti Lismawati ${ }^{1}$, Laelatul Anisah ${ }^{2}$, Mochamad Widjanarko ${ }^{3}$ Jurnal Mahasiswa BK An-Nur : Berbeda, Bermakna, Mulia

Volume 7 Nomor 3 Tahun 2021

Tersedia Online: https://ojs.uniska-bjm.ac.id/index.php/AN-NUR p-ISSN. 2460-9722 | e-ISSN. 2622-8297

koefisien korelasi kedua variabel rx1y $=0,576$ dengan $\mathrm{p}=0,000(\mathrm{p}<0,01)$. Artinya semakin tinggi kelekatan anak pada ibu maka semakin tinggi pula kemandirian yang terjadi pada siswa TK IT Ulul Albaab Weleri. Begitu pula sebaliknya, semakin rendah kelekatan anak pada ibu maka semakin rendah pula kemandirian yang terjadi pada siswa TK IT Ulul Albaab Weleri. Dengan begitu hipotesis minor satu yang diajukan pada penelitian ini diterima. Selengkapnya dapat dilihat pada tabel 5 .

6. Uji hipotesis minor dua

Uji hipotesis minor dua yang dilakukan dengan teknik korelasi Product Moment pada program SPSS 15.00 for Windows menunjukkan adanya hubungan positif yang signifikan antara variabel kepercayaan diri dengan kemandirian, dimana koefisien korelasi kedua variabel $\mathrm{rx} 2 \mathrm{y}=$ 0,496 dengan $\mathrm{p}=0,000(\mathrm{p}<0,01)$. Artinya semakin tinggi kepercayaan diri maka semakin tinggi pula kemandirian yang terjadi pada siswa TK IT Ulul Albaab Weleri. Begitu pula sebaliknya, semakin rendah kepercayaan diri maka semakin rendah pula kemandirian yang terjadi pada siswa TK IT Ulul Albaab Weleri. Dengan begitu hipotesis minor dua yang diajukan pada penelitian ini diterima. Selengkapnya dapat dilihat pada tabel 5.

Tabel 1

Uji Normalitas

One-Sample Kolmogorov-Smirnov Tes

\begin{tabular}{|ll|r|r|r|}
\hline & & \multicolumn{2}{|c|}{ Kelekatan } \\
Anak & Kepercayaan Diri & Kemandirian \\
\hline N & & 60 & 60 & 60 \\
Normal Parameters(a,b) & Mean & 28,70 & 90,750 & 60,283 \\
Most Extreme Differences & Std. Deviation & 6,946 & 13,2609 & 9,1264 \\
& Absolute &, 149 &, 139 &, 102 \\
& Positive &, 149 &, 139 &, 102 \\
Kolmogorov-Smirnov Z & Negative &,- 105 &,- 083 &,- 059 \\
Asymp. Sig. (2-tailed) & & 1,158 & 1,078 &, 790 \\
\end{tabular}

a Test distribution is Normal.

b Calculated from data.

Tabel 2

Uji Linieritas Antara Kelekatan Anak Pada ibu dengan Kemandirian ANOVA TABLE

\begin{tabular}{|c|c|c|c|c|c|c|c|}
\hline & & & $\begin{array}{l}\text { Sum of } \\
\text { Squares }\end{array}$ & $\mathrm{df}$ & $\begin{array}{l}\text { Mean } \\
\text { Square }\end{array}$ & $\mathrm{F}$ & Sig. \\
\hline \multirow{5}{*}{$\begin{array}{l}\text { Kemandirian * } \\
\text { Kelekatan } \\
\text { Anak }\end{array}$} & Between Groups & (Combined) & 2673,261 & 17 & 157,251 & 2,947 &, 002 \\
\hline & & Linearity & 1633,095 & 1 & 1633,095 & 30,608 & ,000 \\
\hline & & $\begin{array}{l}\text { Deviation from } \\
\text { Linearity }\end{array}$ & 1040,166 & 16 & 65,010 & 1,218 & ,295 \\
\hline & Within Groups & & 2240,922 & 42 & 53,355 & & \\
\hline & Total & & 4914,183 & 59 & & & \\
\hline
\end{tabular}

Dipublikasikan Oleh :

UPT Publikasi dan Pengelolaan Jurnal

Universitas Islam Kalimantan Muhammad Arsyad Al-Banjari Banjarmasin 
Siti Lismawati ${ }^{1}$, Laelatul Anisah ${ }^{2}$, Mochamad Widjanarko ${ }^{3}$ Jurnal Mahasiswa BK An-Nur : Berbeda, Bermakna, Mulia

Volume 7 Nomor 3 Tahun 2021

Tersedia Online: https://ojs.uniska-bjm.ac.id/index.php/AN-NUR p-ISSN. 2460-9722 | e-ISSN. 2622-8297

Tabel 3

Uji Linieritas Antara Kepercayaan Diri dengan Kemandirian ANOVA TABLE

\begin{tabular}{|c|c|c|c|c|c|c|c|}
\hline & & & $\begin{array}{l}\text { Sum of } \\
\text { Squares }\end{array}$ & df & $\begin{array}{l}\text { Mean } \\
\text { Square }\end{array}$ & $\mathrm{F}$ & Sig. \\
\hline \multirow{5}{*}{$\begin{array}{l}\text { Kemandirian * } \\
\text { Kepercayaan Diri }\end{array}$} & \multirow{3}{*}{$\begin{array}{l}\text { Between } \\
\text { Groups }\end{array}$} & (Combined)9 & 3207,100 & 35 & 91,631 & 1,288 & ,261 \\
\hline & & Linearity & 1210,738 & 1 & 1210,738 & 17,022 &, 000 \\
\hline & & Deviation from Linearity & 1996,362 & 34 & 58,717 &, 825 & ,701 \\
\hline & \multicolumn{2}{|c|}{ Within Groups } & 1707,083 & 24 & 71,128 & & \\
\hline & \multicolumn{2}{|l|}{ Total } & 4914,183 & 59 & & & \\
\hline
\end{tabular}

Tabel 4

Uji Multikolinieritas

\begin{tabular}{|c|lc|}
\hline Model & \multicolumn{2}{|c|}{ Collinearity Statistics } \\
\cline { 2 - 3 } & Tolerence & VIF \\
\hline $\begin{array}{c}\text { Kelekatan Anak Pada Ibu } \\
\text { Kepercayaan Diri }\end{array}$ & 0,133 & 7,524 \\
& 0,133 & 7,524 \\
\hline
\end{tabular}

Tabel 5

Uji Hipotesis

\begin{tabular}{|ll|r|r|r|}
\hline & & & & \\
& & Kemandirian & Kelekatan Anak & Kepercayaan Diri \\
\hline Kemandirian & Pearson Correlation &, $587(* *)$ &, $576(* *)$ &, $496(* *)$ \\
& Sig. (2-tailed) & &, 000 &, 000 \\
Kelekatan Anak & $\mathrm{N}$ & 60 & 60 & 60 \\
& Pearson Correlation &, $576(* *)$ &, 000 &, $931(* *)$ \\
& Sig. (2-tailed) & 60 & 60 &, 000 \\
Kepercayaan Diri & $\mathrm{N}$ &, $496(* *)$ &, 90 \\
& Pearson Correlation &, 000 & 60 &, 000 \\
& Sig. (2-tailed) & 60 & 1 \\
& $\mathrm{~N}$ & 60 \\
\hline
\end{tabular}

** Correlation is significant at the 0.01 level (2-tailed).

Berdasarkan uji hipotesis minor satu menunjukkan adanya hubungan positif yang signifikan antara variabel kelekatan anak pada ibu dengan kemandirian, dimana koefisien korelasi kedua variabel $\mathrm{rx} 1 \mathrm{y}=0,576$ dengan $\mathrm{p}=0,000(\mathrm{p}<0,01)$. Artinya semakin tinggi kelekatan anak pada ibu maka semakin tinggi pula kemandirian yang terjadi pada siswa TK IT Ulul Albaab Weleri. Hasil yang diperoleh dalam penelitian ini sesuai dengan penelitian yang dilakukan oleh dilakukan oleh Imul Puryanti tahun 2013. Hasil penelitian tersebut menunjukkan ada hubungan antara Kelekatan anak pada Ibu dengan Kemandirian di sekolah.

Hasil penelitian yang diperoleh sesuai dengan pendapat Bowlby (dalam Upton, 2012) anak yang mendapatkan kelekatan (attachment) yang cukup pada masa awal perkembangannya akan merasa dirinya aman (secure) dan lebih positif terhadap

Dipublikasikan Oleh :

UPT Publikasi dan Pengelolaan Jurnal

Universitas Islam Kalimantan Muhammad Arsyad Al-Banjari Banjarmasin 
Siti Lismawati ${ }^{1}$, Laelatul Anisah ${ }^{2}$, Mochamad Widjanarko ${ }^{3}$ Jurnal Mahasiswa BK An-Nur : Berbeda, Bermakna, Mulia

Volume 7 Nomor 3 Tahun 2021

Tersedia Online: https://ojs.uniska-bjm.ac.id/index.php/AN-NUR

p-ISSN. 2460-9722 | e-ISSN. 2622-8297

kelompoknya, menunjukkan ketertarikan yang lebih besar terhadap orang lain. Menurut Anapratiwi, Handayani dan Kurniawati (2013), yang menyatakan bahwa anak yang memiliki kelekatan aman pada ibu akan memiliki kemampuan sosialisasi yang baik, lebih mudah bersahabat, memiliki hubungan yang sehat, dan mudah beradaptasi dengan lingkungan sosial karena percaya lingkungan yang mereka tempati dapat memberikan kenyamanan dan keamanan.

Hasil uji hipotesis minor dua menunjukkan adanya hubungan positif yang signifikan antara variabel kepercayaan diri dengan kemandirian, dimana koefisien korelasi kedua variabel rx2y = 0,496 dengan $\mathrm{p}=0,000(\mathrm{p}<0,01)$. Artinya semakin tinggi kepercayaan diri maka semakin tinggi pula kemandirian yang terjadi pada siswa TK IT Ulul Albaab Weleri. Penelitian ini relevan dengan penelitian sebelumnya yang dilakukan oleh dilakukan oleh Nailis Saidah tahun 2014. Hasil penelitian ini menunjukkan adanya hubungan antara kepercayaan diri dengan kemandirian belajar siswa. Selain itu hasil penelitian ini sesuai dengan pendapat Menurut Lauster (dalam Ghufron dan Risnawati, 2012), orang yang mempunyai rasa percaya diri yang tinggi pada umumnya mudah bergaul secara fleksibel, mempunyai toleransi yang cukup baik, bersikap positif, dan tidak mudah terpengaruh orang lain dalam bertindak serta mampu menentukan langkah- langkah dalam menyelesaikan suatu masalah.

Lauster menambahkan anak yang memiliki percaya diri mampu bertindak dalam mengambil keputusan terhadap diri yang dilakukan secara mandiri atau tanpa adanya keterlibatan orang lain dan mampu untuk meyakini tindakan yang diambil. Hasil uji hipotesis mayor menunjukkan bahwa ada hubungan antara ketiga variabel dimana koefisiensi dari ketiga variabel hasil $\mathrm{Rx} 1,2 \mathrm{y}=0,587$ dengan FHitung $=14,986$ dan $p=0,000(p<0,01)$. Penelitian ini sesuai dengan pendapat dari Brewer (dalam Yamin \& Sanan, 2010) menyatakan bahwa kemandirian anak dapat dilihat dalam kemampuan untuk berani memilih, berani tampil bernyanyi di depan temanya dan dipengaruhi oleh sikap dan kelekatan antara orang tua terhadap anaknya.

\section{PENUTUP}

Berdasarkan hasil analisis data menunjukan bahwa hipotesis mayor yang diajukan diterima, yaitu bahwa ada hubungan antara kelekatan anak pada ibu dan kepercayaan diri dengan kemandirian pada siswa TK di Weleri. Besarnya pengaruh kelekatan anak dan kepercayaan diri dengan kemandirian, tampak pada sumbangan efektif sebesar $34,5 \%$ dan $65,5 \%$. Selain itu pada uji hipotesis minor satu yang diajukan diterima, yaitu bahwa adanya hubungan positif antara kelekatan anak dengan kemandirian, dengan sumbangan efektif sebesar 19,3\%. Sedangkan pada uji hipotesis minor dua yang diajukan menunjukan diterima, yaitu bahwa adanya hubungan positif antara kepercayaan diri dengan kemandirian, dengan sumbangan efektif sebesar $15,07 \%$.

Saran

Berdasarkan hasil penelitian yang menunjukkan adanya hubungan antara kelekatan anak dan kepercayaan diri dengan kemandirian, maka orang tua diharapkan memiliki hubungan yang baik dan menyenangkan antara ibu dan anak. Memenuhi kebutuhan akan kasih sayang dan perhatian anak tercukupi, sehingga anak lebih mempunyai keyakinan dan kemampuan untuk mengadakan interaksi dengan orang lain dan tidak tergantung bantuan ataupun aksi dari orang lain. Bagi peneliti selanjutnya yang tertarik dengan topik yang sama, disarankan untuk mempertimbangkan variabel lain seperti pola asuh orang tua, urutan posisi anak, dan lain sebagainya yang diduga turut berperan dalam mempengaruhi kemandirian.

\section{REFERENSI}

Anapratiwi, D., Handayani, S.L.D., dan Kurniawati, Y. (2013). Hubungan antara Kelekatan Anak pada Ibu dengan Kemampuan Sosialisasi Anak Usia 4-5 tahun (studi pada RA Sinar Pelangi dan RA Al Iman Kecamatan Gunungpati Semarang. Indonesian Journal of Early Childhood Education Studies, 2 (2), 27

Cenceng. (2015). Perilaku Kelekatan pada Anak Usia Dini (Perspektif Jhon Bowlby). Jurnal Lentera, 70 (1), 141-153.

Desmita. (2011). Psikologi perkembangan peserta didik. PT Remaja Rosdakarya. Bandung.

Eliasa, E. I. (2011) Pentingnya Kelekatakan Orang Tua Dalam Internal Working Model Untuk Pembentukan Karaktr Anak. Skripsi. Fakultas

Dipublikasikan Oleh :

UPT Publikasi dan Pengelolaan Jurnal

Universitas Islam Kalimantan Muhammad Arsyad Al-Banjari Banjarmasin 
Siti Lismawati ${ }^{1}$, Laelatul Anisah ${ }^{2}$, Mochamad Widjanarko ${ }^{3}$ Jurnal Mahasiswa BK An-Nur : Berbeda, Bermakna, Mulia

Volume 7 Nomor 3 Tahun 2021

Tersedia Online: https://ojs.uniska-bjm.ac.id/index.php/AN-NUR

p-ISSN. 2460-9722 | e-ISSN. 2622-8297

Ilmu Pendidikan, Universitas Negeri

Yogyakarta.

Ionescu, A.M. (2014). Intersubjectivity and Relational Health In Mother and Child Attachment Dimensions. Procedia-Social and Behavioral Science, 163 (1), 159-168.

Lauster. (2013). Mengajarkan Emotional Intelligence pada Anak. (Alih Bahasa: Alex Tri Kantjono). Jakarta: Gramedia Pustaka Utama.

Nayla, M. (2010). Hubungan Urutan Kelahiran dalam Keluarga dengan Kemandirian Anak Usia Dini di TK Madinah Malang. (Skripsi). Fakultas Psikologi UIN, Malang.

Nurhayati, H. (2015). Hubungan Kelekatan Aman (Secure Attachment) Anak Pada Orangtua Dengan Kemandirian Anak Kelompok B TK PKK 37 Dodogan Jatimulyo Dlingo Bantul. (Skripsi). Universitas Negeri Yogyakarta.

Risnawita, Rini dan Ghufron Nur M. (2010). Teoriteori Psikologi. Yogyakarta: Ar Ruzz Media Grup.

Sjarkawi. (2010). Pembentukan Kepribadian Anak. Jakarta: Bumi Aksara.

Suryana, D. (2020). Pendidikan Anak Usia Dini : Stimulasi dan Perkembangan Anak. Jakarta : Prenada Media.

Undang-undang Nomor 20 tahun 2003 tentang Sistem Pendidikan Nasional.

Yamin, M. dan Sanan, J. (2010). Panduan Pendidikan Anak Usia Dini. Jakarta : Gaung Persada.

Upton, P. (2012). Psikologi. Jakarta : Erlangga.

Dipublikasikan Oleh :

UPT Publikasi dan Pengelolaan Jurnal

Universitas Islam Kalimantan Muhammad Arsyad Al-Banjari Banjarmasin 